\title{
Leverage Capability in Controlling Free Cash Flow to Improve Financial Performance
}

\author{
Nila Tristiarini \\ Faculty of Economics and Business \\ University of Dian Nuswantoro \\ Semarang, Indonesia \\ nila.tristiarini@dsn.dinus.ac.id
}

\author{
Ririh Dian Pratiwi \\ Faculty of Economics and Business \\ University of Dian Nuswantoro \\ Semarang, Indonesia \\ ririh.dian.pratiwi@dsn.dinus.ac.id
}

\begin{abstract}
Free Cash Flow, in general, being a problem for the company if it is not good in controlling. The manager can use free cash flow for actions that can harm the company. Leverage is a cost that can control the usage of free cash flow for the company's activity, which in turn can improve financial performance. The purpose of this study is to examine the role of leverage in mediating the relationship between free cash flow and financial performance. The research variable consists of Free Cash Flow as the independent variable, the Leverage as the mediator and Financial Performance as the dependent variable. The population of this research is manufacturing companies listed on the Indonesia Stock Exchange periods 2011-2015. The sampling method is purposive sampling with criteria, and the samples that meet the criterion are 70 manufacturing companies. The research model is used Warp PLS 3.0. The results show that free cash flow has an effect on financial performance, and Leverage mediates the relationships between free cash flow and financial performance. This research contribute a novelty of science in the field of management accounting, and has positive implications for companies in determining control strategies of free cash flow through the leverage could improve the financial performance.
\end{abstract}

\section{Keywords-Leverage, Free Cash Flow, Financial Performance}

\section{INTRODUCTION}

Theory of the firm Jensen \& Meckling [16], stated that the company's primary goal is profit maximization for shareholders. All corporate activities are intended to meet the interests of shareholders. Companies can make profit maximization if can control and manage the finance to improve financial performance. Free Cash Flow is one tool to measure the company's financial performance and show the amount of cash owned by the company after performing maintenance or development costs of the required assets [1], [11]. Free Cash Flow is an important application for shareholders in assessing the financial health of the company. Managers who invest in Free Cash Flow in projects with today's positive net worth (NPV) as a result of efficient use of their resources will contribute to the increase in corporate value. When it cannot control free cash flow properly, it can otherwise lower the value of the company.

Differences in the concept of free cash flow control can occur because of differences in control and ownership of a company, i.e., the manager's interests and shareholders, causing agency problems [16]. After observing agency issues, Jensen [16] used agency theory as a starting point for proposing a free cash flow hypothesis. According to this hypothesis, corporate managers prefer to have free cash flow that they easily manipulate. They tend to use free cash flow for their benefit rather than the interests of shareholders. Managers prioritize their interests, making the wrong spending or decisions that result in losses known as agency costs that negatively impact the company's performance. According to the free cash flow hypothesis, a negative correlation exists between the firm's performance and the amount of free cash flow under manager control [13].

Titman, et al [24] and Dechow, et al [19] argued that company performance negatively affected by overinvestment in the use of free cash flow under manager control. The work of Park and Jang [13], Heydari et al. [9], Brush et al. [27] and Wang [7] also reveal a negative correlation between performance and free cash flow.

Free cash flow can be controlled one of them through debt financing. Debt financing will reduce the cash flow that ultimately has a positive effect on the performance of the company. It is in accordance with the results of research conducted by Rozeff [18] and Easterbrook [5] who found that debt financing is needed to lower agency costs as reflected in free cash flow.

The company's funding decision concerns the decision on the shape and composition of funding to be used by the company [6]. In general, funds can be obtained from outside the company (external financing) and from inside the company (internal financing). Debt is funding obtained from external financing [21]. Debt is all financial obligations of a company that has not been fulfilled to other parties, where the debt is a source of funds or capital of a company. Debt is a liability of a company arising from past transactions and payments made by cash or goods, and services in the future. According to Taani [14], that debt is an economic sacrifice that the company must make in the future due to previous actions or transactions. The economic sacrifice can be in the form of money, assets, services, or by doing a particular job. Debt results in a bond that entitles the creditor to claim the company's assets. 
From the background of the above, this study has a purpose to perform empirical testing whether leverage can the opportunistic behavior of managers in through the utilization of free cash flow to improve financial performance. The originality of this research lies in the empirical proof of leverage ability to control free cash flow which ultimately can improve financial performance, while the research a different direction that is free cash flow and leverage have a negative influence on financial performance.

\section{LITERATURE REVIEW}

Agency Theory by Jensen \& Meckling [16] states that between owner and management have different interests. The primary principle of this theory states the existence of a working relationship between the party that gives authority (principal), namely the owner with the party who receives the authority (agent), namely manager. The working relationship is based on each side trying to enlarge his advantage. Leverage capability in controlling free cash flow according to agency theory, states that controlling the opportunistic behavior of managers through third parties, namely creditors. Debt financing can enlarge the authority of the creditor to supervise the management's activities so as not to harm the company. It is also consistent with the Monitoring Effect Theory which states that with effective supervision it can encourage managers to work by the company's primary objective of maximizing corporate value [20].

\section{A. Effect of Free Cash Flow on Financial Performance}

Free cash flows are the cash flows available to resource providers after paying all costs and business requirements necessary to maintain them in the form of operations. Proper management of working capital components allows companies to have excess free cash flow which in turn can be a profitable investment to generate profits for the company [12]. Cutting costs have a significant effect on free cash flow owned by the company; this allows the company to have the additional finance to take advantage of profitable investment projects that can generate higher returns. Free cash flow affects not only the company's revenue and profitability but also the balance sheet management. If the company fails to manage net working capital well then, free cash flow may be lower than the net profit of the company. The above mentioned by previous research conducted by Wang [7].

\section{$\mathrm{H} 1=$ There is effect of Free Cash Flow to Financial Performance}

\section{B. Effect of Free Cash Flow on Leverage}

Companies whose capital structure uses debt can reduce free cash flow. By using more leverage then free cash flow will be utilized by managers to pay debts and interest payments. The high level of leverage in the company's capital structure also increases the risk of corporate bankruptcy. With companies using debt at the capital structure, it will give the creditor the power that they have rights to the company's assets used as collateral if the company does not meet its financial obligations. The risk of bankruptcy forces managers to work in an efficient way that increases the profitability of a company. Managers are at risk of losing their jobs in the event of bankruptcy so they take advantage of company resources in positive NPV projects rather than throwing them into their interests. Debt provides shielding against free cash flow agency costs by reducing free cash flow and hindering management to maximize its interests. The above mentioned by previous research conducted by Afza and Mirza [26], Fatma and Chichti [4], Zhang [28], Utami and Inanga [25].

\section{$\mathrm{H} 2=$ There is influence of Free Cash Flow to Leverage}

\section{Effect of Leverage on Financial Performance}

The Modigliani \& Miller approach argues that funding decisions will be relevant in perfect market conditions and there is a tax. It is because in general the interest paid (from the debt) can be used to reduce the income taxed. Because saving taxes is a benefit to company owners, then the value of the firm that uses debt will be greater than the value of companies that do not use debt in the capital structure. The above is different from that stated by Myers and Maljuf [22] which explained that the relationship between debt policy with the profitability of the company which states that more profitable companies will reduce its debt. The company prefers to finance their company by using the source of funds obtained from the internal company. The above mentioned by previous research conducted by Akinmulegun [23]; Alcock et al. [10]; Berger and Bonaccorsi [2].

\section{$\mathrm{H} 3=$ There is a leverage effect on Financial Performance}

\section{Leverage Mediating Free Cash Flow Relation with Financial Performance}

Debt policy has the effect of disciplining manager behavior. The Debt will reduce agency conflicts and increase company value. Increased debt increases leverage thereby increasing the probability of financial difficulty or bankruptcy. Bankruptcy concerns encourage managers to be efficient, thus improving agency costs through free cash flow. Debt forces the company to pay principal and interest to reduce free cash flow and lower the incentive of managers to behave themselves. Haris and Raviv [15] concluded by empirical evidence demonstrating the consistency of the theory that debt can decrease agency conflicts through the efficient use of free cash flow and ultimately increase corporate value. However, the debt increases the marginal cost. Additional debt funds caused shareholders to resort to more risky projects [16]. The reason is if the project is successful, can protect the interests of creditors (debt holder) on interest and loan principal, and the external investor enjoys the rest of the profit. But if the project fails, the creditor bears the risks of rising costs, because shareholders have limited liability. The lender anticipates this risk by transferring the risk to shareholders by increasing the cost of debt.

$\mathrm{H} 4=$ There is Leverage mediation to the free cash flow relationship with Financial Performance

\section{RESEARCH METHOD}

The population in the observation period of 2011-2015 is manufacturing companies listed on the Indonesia Stock 
Exchange totaling 154 companies. Then according to the criteria of sample selection by using purposive sampling method then obtained 70 manufacturing companies.

Exogenous variable in this research is Free Cash Flow (FCF). FCF is the free cash flow that remains after the company pays its operational expenses and investment needs. In this study FCF is calculated in the following way:

Free Cash Flow $=\frac{\mathrm{NI}_{\mathrm{it}}-\Delta \mathrm{PPE}_{\mathrm{it}}-\Delta \mathrm{ICap}_{\mathrm{it}}}{T A_{\mathrm{it}}}$

Where :

$$
\begin{array}{ll}
\mathrm{NI} & =\text { Net profit } \\
\Delta \mathrm{ICap} & =\text { Changes in Working capital } \\
\Delta \mathrm{PPE} & =\text { Changes in fix assets } \\
\mathrm{TA} & =\text { Total Assets }
\end{array}
$$

Endogenous variable in this research is Financial Performance. Financial Performance is a certain performance that realizes the profit and loss in the period concerned. Thus, Financial Performance is a measure of how well a company can use its assets in running a business and earning revenue. Financial Performance Measurement in this study using Net Profit Margin (NPM). The NPM measurement uses the following formula :

$$
\mathrm{NPM}=\frac{\text { Earning after Tax }}{\text { Net Sales }}
$$

Variable Mediation in this research is Leverage. Leverage is a level of the company's ability to use assets and or funds that have fixed expenses (debt and/or preferred shares) to realize the company's goal to maximize the wealth of the company owner. The Leverage measurement uses the following formula :

$$
\text { Leverage }=\frac{\text { Total Liabilities }}{\text { Total Asset }}
$$

This research uses Structural Equation Modeling (SEM) analysis tool with Warp PLS version 3.00 program used to test the hypothesis. The use of statistical analysis tools is due it has several advantages that can perform statistical tests on mediating variables without the need to do repetitive testing to be able to answer the hypothesis. This analysis tool is designed to solve problems such as small sample size, multivariate non-distributed data, missing values, and multi coloniality among exogenous variables [8]. The research framework can be described by using path analysis in Figure 1:

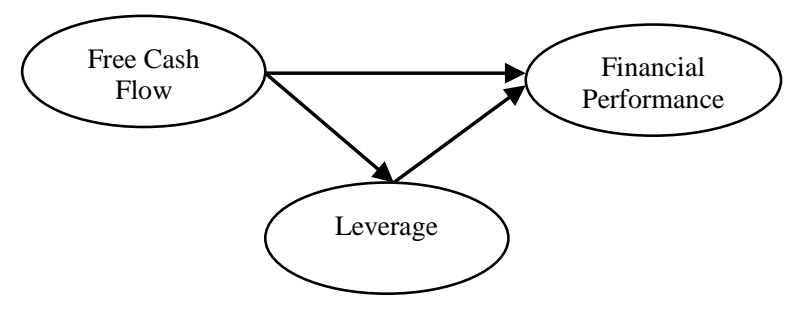

Figure 1. Conceptual Research Framework

\section{RESULT AND DISCUSSION}

\subsection{Descriptive statistics}

Descriptive statistics are used to explain the characteristics of research variables used. Therefore the explanation of descriptive statistics of research variables is as follows:

Table 1. Descriptive Statistics of Research Variables

\begin{tabular}{|l|c|r|r|r|r|}
\hline Variable & N & \multicolumn{1}{|c|}{ Min } & \multicolumn{1}{c|}{ Max } & \multicolumn{1}{c|}{ Mean } & \multicolumn{1}{c|}{$\begin{array}{c}\text { Std. } \\
\text { Deviation }\end{array}$} \\
\hline FCF & 70 & 0.0086 & 0.5820 & 0.1141 & 0.1273 \\
\hline LEV & 70 & 0.1800 & 0.7500 & 0.4670 & 0.1384 \\
\hline FP & 70 & 1.11 & 32.7600 & 10.1040 & 8.7271 \\
\hline
\end{tabular}

Source: processed data used in this study; FCF: Free Cash Flow; LEV: Leverage; FP: Financial Performance

From table 1 the descriptive statistics of the research variables show that the FCF variable has an average of 0.1141 with a standard deviation of 1,273. The average value for Leverage is 0.4670 , with a standard deviation of 0.1384 . The average value of Financial Performance is 10.1040 with a standard deviation of 8.7271 .

\subsection{Hypothesis testing}

To be able to answer the hypothesis of mediation research it must be done first making direct path analysis which describes the causality relationship between exogenous variables that is Free Cash Flow with the endogenous variable that is Financial Performance. So, after run-test, direct path analysis is obtained as shown in Figure 2:

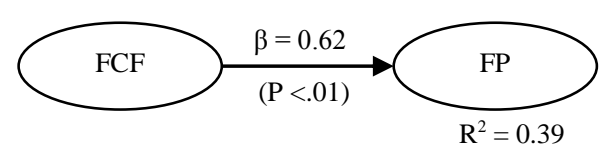

Figure 2. Direct Path Analysis

Source: processed data used in this study

Figure 2 above shows the causality relationship between variables, i.e., Free Cash Flow as an exogenous variable with Financial Performance as an endogenous variable, and which has a coefficient path value of 0.62 with a p-value $(<0.01)$. Financial Performance has R square value of 0.39 .

Furthermore, a full path analysis is tested to be able to answer the next hypothesis, especially to prove the hypothesis testing mediation. Testing using causality relationship between exogenous variables (Free cash flow), variable mediation (Leverage) and endogenous variable (Financial Performance). The results of the full path analysis can be illustrated in Figure 3 below: 


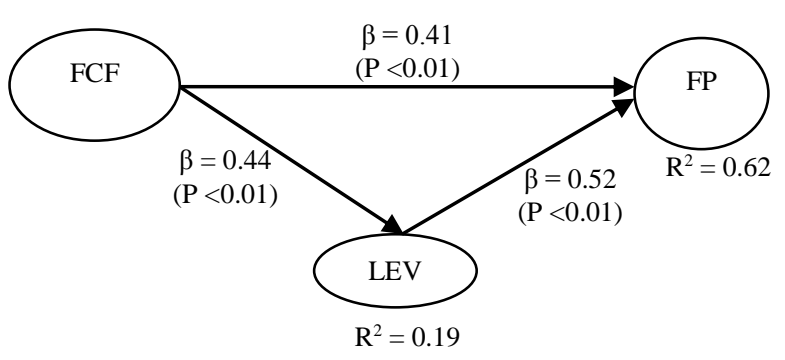

Figure 3. Full Path Analysis

Figure 3 above shows the causality relationship between variables, namely Free Cash Flow as an exogenous variable with Financial Performance as an endogenous variable, and Leverage as a mediating, which has coefficient path value between Free Cash Flow with Financial Performance is 0.41 with $\mathrm{p}$-value $<0.01$. The path coefficient value between Free Cash Flow with Leverage of 0.44 with p-value $<0,01$; while the coefficient path value between Leverage with Financial Performance is -0.52 with $\mathrm{p}$-value $<0.01$. Leverage has $\mathrm{R}$ square value of 0.19 . Financial Performance has $\mathrm{R}$ square value of 0.62 .

The results of Path coefficients and $\mathrm{P}$ values to see the magnitude of coefficient and significance level are as follows:

Table 2. Result Path coefficients and $P$ value

\begin{tabular}{|l|r|r|r|r|}
\hline \multirow{2}{*}{ Path } & \multicolumn{2}{|c|}{ Direct Effect } & \multicolumn{2}{c|}{ Indirect Effect } \\
\cline { 2 - 5 } & Coefficient & P-Value & Coefficient & P-Value \\
\hline FCF $\rightarrow$ FP & 0.62 & $<0.01$ & 0.41 & $<0.01$ \\
\hline FCF $\rightarrow$ LEV & & & 0.44 & $<0.01$ \\
\hline LEV $\rightarrow$ FP & & & 0.52 & $<0.01$ \\
\hline
\end{tabular}

Source: processed data used in this study; FCF: Free Cash Flow; LEV: Leverage; FP: Financial Performance

Table 2 shows the test results that the direct effect coefficient of FCF to FP is 0.62 and significant at $p<0.01$. The result shows that accept the first hypothesis (H1) that is that Free Cash Flow has a significant effect on Financial Performance. These results indicate that the first requirement to be a mediating variable is the FCF coefficient to FP significant.

The result of indirect effect indicates that the coefficient of FCF path to LEV is 0.44 and significant at $p<0,01$. The result shows that accept the second hypothesis (H2) that the Free Cash Flow significant effect on Leverage. These results indicate that the second requirement to be a mediating variable is the FCF coefficient to LEV is significant. Furthermore, the LEV line coefficient to FP is 0.52 and significant at $p<0.01$. The result shows that accept the third hypothesis (H3) is that Leverage has a significant effect on Financial Performance. These results indicate that the third requirement to be a mediating variable is the LEV coefficient to FP is significant.
FCF test result to FP shows that the direct effect coefficient is 0.62 and significant $\mathrm{p}<0.01$. The results show that the indirect effect coefficient of FCF to FP decreases to 0.41 from 0.62 but remains significant. The result represent that Leverage is a partial mediation. The result shows that accept the fourth hypothesis (H4) that Leverage mediates the Free Cash Flow relationship with Financial Performance.

\subsection{Discussion}

The results showed that Free cash flow partly influenced by financial performance. The Result shows that when the value of Free Cash Flow increases, it will positively improve financial performance. Good and proper free cash flow management could a profitable investment to improve financial performance for the company.

Free cash flow also shows a partial influence on leverage. This shows that when the value of Free Cash Flow increases, it will positively increase leverage. The results of this study show that companies use free cash flow for debt repayment. Because maximizing the use of free cash flow to pay off debt will force managers to work more effectively and efficiently, thus avoiding the opportunistic behavior of managers. Debt provides shielding against free cash flow agency costs by reducing free cash flow and hindering management to maximize its own interests.

The results also show that Leverage partly influenced by financial performance. This means that when the value of leverage is high then the financial performance will rise. Companies that have high leverage rates will apply the company's resources in profitable activities to have an ability to pay debts, to improve financial performance.

This research also shows the result that Leverage mediates the relationship between free cash flow and Financial Performance. The use of free cash flow for debt repayment can make the lenders involved to supervise manager's performance so that it can curb the manager's opportunistic behavior to maximize his own interests, so the manager will use free cash flow for activities that do not harm the company.

The above results are consistent with agency theory [16], namely that managers must control their activities to maximize corporate profits, and not rank the interests of managers themselves. Inappropriate with monitoring effect theory [20], managers' activity control through involve of the creditor side who oversees the manager in carrying out its activities capable to pay the debt, so that use of free cash flow that is within the control manager for activities that give the rate of return positive to improve the company's financial performance.

\section{CONCLUSION AND IMPLICATION}

The results can prove that the ability of companies in using Leverage can control the use of free cash flow to improve the financial performance of the company. It shows that the use of free cash flow can be used by shareholders to measure the performance of managers in maximizing shareholder profits. It is by the monitoring effect theory where managers can be curbed by the opportunistic nature by maximizing the 
utilization of free cash flow to increase leverage to maximize financial performance. The implication of this research is to give conceptual new science about the strategy that can be done by the company to improve financial performance with controlling utilization of free cash flow through leverage utilization.

\section{REFERENCES}

[1] A., Al-Zararee and A. Al-Azzawi, "The Impact of Free Cash Flow on Market Value of Firm," Global Review of Accounting and Finance, Vol. 5 (2), 2014, pp. 56-63.

[2] A. Berger and P.E. Bonaccorsi, "Capital Structure and Firm Performance: A New Approach to Testing Agency Theory and Application to The Banking Industry," Journal of Banking and Finance Vol. 30, 2006, pp. 1065-1102

[3] A. Khan, A. Kaleem and M. Sajid Nasir, "The Impact of Financial Leverage on Agency Cost of Free Cash Flows, Evidence from Manufacturing Sector of Pakistan," Journal of Basic and Applied Scientific Research Vol 2 (1), 2012, pp 6694-6700.

[4] B.M. Fatma and J. Chichti, "Interactions between Free Cash Flow, Debt Policy, and Structure of Governance: Three Stage Least Square Simultaneous Model Approach," Journal of Management Research, Vol 3 (2), 2011, pp. 1-34.

[5] F.H., Easterbrook, "Two Agency-Cost Explanations of Dividends," American Economic Review, Vol. 74, 1984, pp. 650-659.

[6] G. Houang and F.S., Song, "The Determinants of Capital Structure: Evidence from China, "China Economic Review, Vol. 14, 2006, pp. 1436.

[7] G.Y. Wang, "The Impact of Free Cash Flow and Agency Costs on Firm Performance," Journal of Service Science and Management, Vol. 03 (04), 2010, pp. 408-418.

[8] H., Latan and I., Ghozali, "Partial Least Squares : Konsep Metode dan Aplikasi Menggunakan Program WarpPLS 3.0, Badan Penerbit Universitas Diponegoro, 2012.

[9] I., Heydari, M., Milad and M. Javadghayedi, "Investigating The Relationship Between Free Cash Flows and Firm Performance: Evidence from Tehran Stock Exchange," Indian Journal Scientific Research, Vol. 4, 2014, pp. 269-279.

[10] J., Alcock, A., Baum, N., Colley and E. Steiner, "The Role of Financial Leverage in The Performance of Private Equity Real Estate Funds, The Journal of Portfolio Management, 2013, pp. 99-110.

[11] J., Byrd, "Financial Policies and The Agency Costs of Free Cash Flow: Evidence from The Oil Industry," International Review of Accounting, Banking, and Finance, Vol. 2(2), 2010, pp. 23-50.

[12] J. Chu, "Agency Cost Under The Restriction of Free Cash Flow," Journal of Service Science and Management, Vol. 4, 2011, pp. 79-85.

[13] K., Park and S., Jang, "Effects of Within-Industry Diversification and Related Diversification Strategies on Firm Performance," International Journal of Hospitality Management, Vol. 33, 2013, pp. 51-60.

[14] K., Taani, "Impact of Working Capital Management Policy and Financial Leverage on Financial Performance: Evidence from Amman Stock Exchange Listed Companies," International Journal of Management Science and Business Research, Vol. 1 (8), 2012, pp. 1017.

[15] M., Harris and A., Raviv, "The Theory of Capital Structure," Journal of Finance, Vol. 49, 1991, pp. 297-355.

[16] M.C., Jensen and W.H., Meckling, "Theory of The Firm: Managerial Behavior, Agency Cost, and Ownership Structure.” Journal of Financial Economics, Vol. 3, 1976, pp. 303-360.

[17] M.C., Jensen, "Agency Costs of Free Cash Flow, Corporate Finance, and Takeovers," American Economic Review, Vol. 76, 1986, pp. 323329.

[18] M.S., Rozeff, "Growth, Beta, and Agency Costs as Determinants of Dividend Payout Ratios," Journal of Financial Research, Vol. 5 (3), 1982, pp. 249-259.
[19] P.M., Dechow, S.A., Richardson and R.G., Sloan, "The Persistence and Pricing of The Cash Component of Earnings," Journal of Accounting Research, Vol. 46 (3), 2008, pp. 537-566.

[20] R. Caers, "Principal-Agent Relationships on The Stewardship-Agency Axis," Non-Profit Management and Leadership Journal, Vol. 17 (1), 2006, pp. 25-47.

[21] S., Akbarian, "The Investigation Effect of Financial Leverage and Environment Risk on Performance Firms of Listed Companies in Tehran Stock Exchange," Journal of Applied Science and Agriculture, Vol. 8 (3), 2013, pp. 249-255.

[22] S.C., Myers, and N. Majluf, "Corporate Financing and Investment Decisions when Firms have Information Investors Do Not have," Journal of Financial Economis, Vol. 13, 1984, pp. 187-221.

[23] S.O., Akinmulegun, "The Effect of Financial Leverage on Corporate Performance of Some Selected Companies in Nigeria," Canadian Social Science, Vol. 8 (1), 2012, pp. 85-91.

[24] S., Titman, K.C.J., Wei, and F., Xie, "Capital Invesments and Stock Return," NBER Working Paper Series, Cambridge, Mass: National Bureau of Economic Research, Vol. 9951, 2003, 2003.

[25] S.R., Utami and E., Inaga, "Agency Cost of Free Cash Flow, Dividend Policy and Financial Leverage of Firms in Indonesia," European Journal of Economics, Finance and Administrative Science, Vol. 33, 2011, pp. 7-24.

[26] T., Afza, and H., Mirza, "Ownership Structure and Cash Flow as Determinants of Corporate Dividend Policy in Pakistan," International Business Research, Vol. 3 (3), 2010, pp. 210-221.

[27] T.H., Brush, P., Bromiley, and M., Hendricks, "The Free Cash Flow Hypothesis for Sales Growth and Firm Performance," Strategic Management Journal, Vol. 21 (4), 2000, pp. 455-472.

[28] Y., Zhang, "Are Debt and Incentive Compensation Substitutes in Controlling The Free Cash Flow Agency Problem?," Financial Management, Vol. 38 (3), 2009, pp. 507-541. 